Universidad de Lima

Facultad de Derecho

Carrera de Derecho

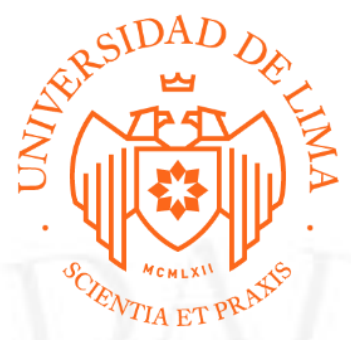

\title{
EXPEDIENTES CIVIL: "MEJOR DERECHO \\ DE PROPIEDAD” Y ADMINISTRATIVO: "BARRERAS BUROCRÁTICAS"
}

Trabajo de suficiencia profesional para optar el Título Profesional de Abogada

Andrea Elizabeth Córdova Silva

Código 20112693

Lima - Perú

Abril de 2019 
EXPEDIENTES CIVIL: "MEJOR DERECHO DE PROPIEDAD"

Materia: Mejor Derecho de Propiedad

$N^{o}$ de Expediente: 2001-00115-0-2402-JR-CI-1

\section{ADMINISTRATIVO: "BARRERAS BUROCRÁTICAS"}

Materia: Barreras Burocráticas

$\mathrm{N}^{\mathrm{o}}$ de Expediente: 000087-2007/CAM 